\title{
Radzenie sobie ze stresem rodziców dzieci $z$ autyzmem
}

\begin{abstract}
Mieczysław Dudek, Radzenie sobie ze stresem rodziców dzieci z autyzmem [Dealing with the stress of parents of autistic children]. Interdyscyplinarne Konteksty Pedagogiki Specjalnej, nr 19, Poznań 2017. Pp. 133-152. Adam Mickiewicz University Press. ISSN 2300-391X
\end{abstract}

Appearing in a disabled child's family is always a source of tremendous stress. This problem is particularly evident when having an autistic child because of its unpredictable and untypical development. Everybody is working out some mechanisms in his or her life to deal with difficult situations. According to Lazarus and Folkman (1987), dealing with stress relies heavily on specific intellectual activities and the appropriate actions to master the requirements that the person assesses as being burdensome or beyond his current remedies. There are many ways to deal with stress. The most common strategies are focused on solving the problem (SSZ), emotional overeating (SSE), and avoidance of distress (SSU) by engaging in substitute activities (ACZ) or seeking social contact (CSA). It is acknowledged that effective way to deal with stress is based on matching the needs and capabilities of the individual. The research included in this article was to investigate the ways of dealing with stress among 130 parents of autistic children.

KEY WORDS: autism, family, stress, dealing with stress 


\section{Wstęp}

Choroba lub zaburzenie rozwojowe dziecka wpływa na system rodziny i jest źródłem stresu, lęku i niepokoju dla każdego członka rodziny. Posiadanie dziecka $\mathrm{z}$ problemami rozwojowymi burzy dotychczasowy porządek w rodzinie, osłabia poczucie bezpieczeństwa. Rodzice dzieci zaburzonych w rozwoju są narażeni na kontakt ze specyficznymi stresorami w środowisku rodzinnym, a przy tym nie mają możliwości zmiany swojej sytuacji. Wieloletnia opieka nad zaburzonym dzieckiem obciąża rodziców poważnymi kosztami zarówno fizycznymi, jak i psychicznymi ${ }^{1}$. Problem ten jest szczególnie widoczny $\mathrm{w}$ przypadku posiadania dziecka $\mathrm{z}$ autyzmem $\mathrm{z}$ racji jego nieprzewidywalnego i nietypowego rozwoju ${ }^{2}$. Dotychczasowe badania potwierdzają, że rodzice dzieci z autyzmem doświadczają zdecydowanie większego napięcia i stresu niż rodzice opiekujący się dziećmi urodzonymi np. z zespołem Downa czy mózgowym porażeniem dziecięcym³ .

Ważnym czynnikiem mającym wpływ na zakres i nasilenie przeżywanych przez rodziców trudności jest trudna i zbyt późna diagnoza autyzmu u dziecka. Nie mniej ważna jest sytuacja socjoekonomiczna rodziny, wykształcenie rodziców, miejsce zamieszkania oraz dostęp do specjalistycznych instytucji zajmujących się wczesną diagnozą i terapią oraz profesjonalnym organizowaniem

${ }^{1}$ A. Twardowski, Sytuacja rodzin dzieci niepetnosprawnych, [w:] Dziecko niepetnosprawne $w$ rodzinie, red. I. Obuchowska, WSiP, Warszawa 2008; A. Garncarz-Podlasko, Sytuacja psychospołeczna rodziców dzieci autystycznych w kontekście zespołu wypalania sit, [w:] Autyzm wyzwaniem naszych czasów, red. T. Gałkowski, J. Kossewska, Wydawnictwo Naukowe Akademii Pedagogicznej, Kraków 2001, s. 209-217.

2 M. Sekułowicz, Niektóre problemy funkcjonowania rodziny dziecka autystycznego, [w:] Autyzm kontrowersje i wyzwania, red. W. Dykcik, Wydawnictwo Eruditus, Poznań 1994, s. 201-207; K. Patyk, Rodzice dzieci autystycznych wobec sytuacji trudnych, „Problemy Opiekuńczo-Wychowawcze” 2009, s. 34-42.

${ }^{3}$ E. Pisula, Małe dziecko $z$ autyzmem, Gdańskie Wydawnictwo Psychologiczne 2005, s. 13-23; N. Johnson, M. Frenn, S. Feetham, P. Simpson, Autism spectrum disorder: parenting stress, family functioning and health-related quality of life, "Family, System \& Health" 2011, 29, s. 232-52. 
opieki i wsparcia ich autystycznego dziecka. W sytuacji braku dostępu do tego typu instytucji, to właśnie na rodzicach spoczywa wiele zadań związanych $\mathrm{z}$ organizowaniem i koordynowaniem niezbędnej terapii, edukacji oraz rehabilitacji dziecku, a czasem wręcz prowadzenie terapii pod nadzorem profesjonalistów ${ }^{4}$. Dużym obciążeniem dla rodziców jest brak wiedzy odnośnie do dostępnych form terapii oraz konieczność dokonania wyboru odpowiedniej w stosunku do potrzeb dziecka opcji terapeutycznej (na ogół rodzice są pozbawieni odpowiedniego wsparcia w tym zakresie). W Polsce sytuacja rodzin z dziećmi z autyzmem jest wciąż zła. Chociaż dostęp do usług diagnostycznych i terapeutycznych nieco się poprawił, to nadal jest on zależny od możliwości ekonomicznych rodziny oraz miejsca jej zamieszkania 5 . W tej sytuacji coraz większe znaczenie ma internet. Rodzice posiadający dostęp do internetu znajdują wiele potrzebnych dla nich informacji, jak również mają możliwość wymiany poglądów z innymi osobami (na forum rodziców).

Specyfika problemów związanych z funkcjonowaniem dziecka $\mathrm{z}$ autyzmem sprawia, że wymaga ono wszechstronnej pomocy. Przekłada się to bezpośrednio na koszt usług w zakresie terapii zwykle są one bardzo wysokie. Kolejnym istotnym mankamentem jest fakt, że większość placówek oferujących potrzebne usługi terapeutyczne znajduje się w dużych ośrodkach miejskich. Sprawia to, że część dzieci zamieszkujących z dala od tych miast może korzystać $\mathrm{z}$ terapii prowadzonej w trybie konsultacyjnym lub też korzystają z usług osób niemających odpowiednich kwalifikacji.

Współczesne trendy w zakresie działań terapeutycznych i wspierających dzieci z autyzmem skierowane są na jak największą aktywizację i zaangażowanie ich rodziców. Przyjmuje się, że dla efektywnej terapii konieczne jest zadbanie o dobry stan zdrowia i dobre samopoczucie obojga rodziców. Wielu autorów podkreśla znacze-

${ }^{4}$ E. Pisula, D. Noińska, Stres rodzicielski i percepcja doświadczeń związanych z opieka nad dzieckiem u rodziców dzieci z autyzmem uczestniczacych w różnych formach terapii, „Psychologia Rozwojowa” 2011, tom 16, nr 3, s. 75-88.

5 Por. A. Rajner, M. Wroniszewski, Można im pomóc. Specjalistyczne ustugi opiekuńcze dla dzieci z autyzmem, SYNAPSIS, Warszawa 2002. 
nie profesjonalnych programów terapeutycznych skierowanych do rodziców dzieci $\mathrm{z}$ niepełnosprawnością ${ }^{6} \mathrm{w}$ tym również dotkniętych problemem autyzmu?

\section{Stres rodzicielski}

Problematyka stresu rodziców wychowujących dzieci z autyzmem jest zagadnieniem istotnym z uwagi na specyfikę wpływu emocjonalnego rodzica (szczególnie kondycji w jakiej rodzic się znajduje) na osobę dziecka oraz na sposób funkcjonowania całej rodziny. Stwierdzenie autyzmu u dziecka jest silnym stresorem dla członków rodziny i wywiera istotny wpływ na relacje między nimi. Potwierdzają to wyniki badań realizowane na świecie od przeszło 40 lat. W dostępnej literaturze przedmiotu autorzy posługują się na ogół ogólną definicją stresu, w której akcentują przyczyny, objawy lub konsekwencje stresu. Do najczęściej wymienianych w podstawowych definicjach zmiennych należą: wielkość, intensywność, długotrwałość i nieprzewidywalność stresorów ${ }^{8}$.

Według Hansa Seylego, twórcy fizjologicznej teorii stresu, jest on nieswoistą reakcją organizmu na stawiane mu wymagania9. Stres może mieć charakter pozytywny (eustres) lub negatywny (dystres). Tzw. pozytywny stres prowadzi do rozwoju osobowości człowieka

${ }^{6}$ Np.: M. Dudek, Dzieci z zespołem ADHD w środowisku rodzinnym. Studium empiryczne, Wydawnictwo Adam Marszałek, Torun 2015.

${ }^{7}$ Np.: P. Randall, J. Parker, Autyzm. Jak pomóc rodzinie, GWP, Gdańsk 2016; H. Jaklewicz, Autyzm wczesnodziecięcy. Diagnoza, przebieg, leczenie, GWP, Gdańsk 1993; T. Gałkowski, Dziecko autystyczne w środowisku rodzinnym, WSiP, Warszawa 1995.

${ }^{8}$ E. Pisula, Psychologiczne problemy rodziców dzieci z zaburzeniami rozwoju, Wydawnictwa UW, Warszawa 1998, s. 48; J. Pyżalski, Wypalenie zawodowe a zdrowie i zachowania zdrowotne pedagogów placówek resocjalizacyjnych, „Medycyna Pracy” 2002, 6, s. 495-499; R. Lazarus, S. Folkman, Stress, appraisal, and coping, International Classification of Diseases 10th Revision. World Health Organization, Springer, New York 2010; R.S. Lazarus, Paradygmat stresu i radzenia sobie, „Nowiny Psychologiczne” 1986, 3-4(40-41).

${ }^{9}$ H. Selye, Stres okietznany, PIW, Warszawa 1979, s. 25. 
i motywuje go do działania, podczas gdy dystres prowadzi do cierpienia i dezorganizacji w działaniu.

W ujęciu psychologicznym z uwagi na różnorodność teorii odnoszących się do teorii stresu, bywa on różnie opisywany i definiowany. Irving L. Janis, twórca teorii napięcia emocjonalnego, określa stres jako zmianę w otoczeniu, która u przeciętnego człowieka wywołuje wysoki stopień napięcia emocjonalnego, które przeszkadza w normalnym funkcjonowaniu ${ }^{10}$.

Definicja I.L. Janisa obejmuje dwa aspekty stresu:

1) sytuację stresową opisywaną za pomocą bodźców wywołujących zaburzenia w zachowaniu,

2) reakcję stresową rozumianą jako wszelkie zmiany w zewnętrznym zachowaniu, uczuciach, postawach, które zostały wywołane przez bodźce stresowe.

Nieco inne ujęcie stresu proponuje Irena Heszen-Niejodek, definiując go „,jako określoną relację między osobą a otoczeniem, która oceniana jest przez osobę jako obciążająca lub przekraczająca jej zasoby i zagrażające jej dobrostanowi"11.

Chociaż istnieje zgodność co do stanowiska, że dystres ma negatywny wpływ na każdy wymiar ludzkiego życia, to jednak coraz częściej pojawia się przekonanie, że nie tyle sam stres jest najbardziej szkodliwy dla człowieka, co raczej poczucie niemożności kontrolowania wydarzeń go wywołujących ${ }^{12}$. Autorzy reprezentujący ten pogląd stoją na stanowisku, że człowiek, który posiada podstawową wiedzę dotyczącą źródeł oraz skutków stresu, jest w stanie łatwiej i szybciej rozpoznać wczesne sygnały ostrzegawcze dotyczące stresu i w pełni ocenić presję, jaką na nim wywiera13.

10 Za: J.F. Terelak, Psychologia stresu, Oficyna Wydawnicza Branta, Bydgoszcz 2001, s. 77.

11 I. Heszen-Niejodek, Teoria stresu psychologicznego i radzenia sobie, [w:] Psychologia, t. 3, red. J. Strelau, GWP, Gdańsk 1999, s. 467.

12 I.L. Janis, Psychological stress: Psychoanalytic and behavioral studies of surgical patients, Wiley, New York 1958.

13 A. Borowicz, Stres rodziców wychowujących dzieci z niepetnosprawnością stuchowa, „Niepełnosprawność - zagadnienia, problemy, rozwiązania” 2012, nr II, s. 58. 
W rezultacie jest także świadomy fizycznych i psychicznych skutków działania stresu.

Przeciążenie rodziców długotrwałą opieką nad dzieckiem z autyzmem, któremu towarzyszy nieustanny stres oraz brak odpowiedniego wsparcia dla rodziny, może prowadzić w konsekwencji do pojawienia się zespołu wypalenie się sił - burn-out syndrome ${ }^{14}$. Wyraża się on głównie w postaci utraty sił psychicznych i fizycznych.

\section{Style radzenia sobie ze stresem}

Przyjmuje się, że stres jest nieodzownym czynnikiem towarzyszącym w procesie dostosowywania się do trudnej sytuacji rodzinnej $\mathrm{w}$ jej codziennym funkcjonowaniu $\mathrm{z}$ dzieckiem $\mathrm{z}$ autyzmem. Sposób odczuwania stresu oraz umiejętność poradzenia sobie z nim zależy od różnorodnych czynników związanych z systemem wsparcia społecznego oraz zasobami osobistymi. Autorzy zajmujący się tą problematyką najczęściej wskazują na: optymizm, prężność psychiczną, poczucie koherencji, wewnętrzne umiejscowienie kontroli oraz pewne cechy osobowości, takie jak: ekstrawersja, ugodowość, otwartość na doświadczenia ${ }^{15}$.

Jan Strelau, traktując stres jako stan będący wynikiem braku równowagi między wymaganiami a możliwościami jednostki, przypisuje radzeniu sobie ze stresem funkcję regulacyjna, która według Autora „polega na utrzymywaniu adekwatnej równowagi pomiędzy wymaganiami a możliwościami lub na redukowaniu rozbieżności pomiędzy wymaganiami a możliwościami"16.

14 T. Gałkowski, Dziecko autystyczne w środowisku rodzinnym, WSiP, Warszawa 1995; Pisula E., Zespót wypalania się sił u rodziców dzieci autystycznych, „Nowiny Pedagogiczne" 1994, 3.

${ }^{15}$ Np.: N. Ogińska-Bulik, Z. Juczyński, Osobowość, stres a zdrowie. Difin, Warszawa 2008; L. Huber, Style adaptacyjne do sytuacji stresowych w różnych grupach wiekowych a choroby cywilizacyjne XXI wieku, „Problemy Higieny i Epidemiologii” 2010, 91(2), s. 268-275.

16 J. Strelau, Temperament a stres: Temperament jako czynnik moderujacy stresory, stan, i skutki stresu oraz radzenie sobie ze stresem, [w:] Człowiek w sytuacji stresu, red. 
Andrew M. Colman poprzez indywidualny styl radzenia sobie ze stresem rozumie zespół cech człowieka odnoszony bezpośrednio do procesów aktywowanych w sytuacji stresowej, przy czym efektywne radzenie sobie ze stresem polega nie tyle na wyborze stylu, co na umiejętnym dobieraniu dostępnych stylów radzenia sobie tak, aby były adekwatne do wymagań konkretnej sytuacji stresowej ${ }^{17}$.

W literaturze przedmiotu istnieje wiele sposobów klasyfikowania stylów radzenia sobie ze stresem. Najczęściej opisywana i wykorzystywana w badaniach jest klasyfikacja, którą podają Norman Endler i James Parker, tj: styl skoncentrowany na zadaniu, skoncentrowany na emocjach oraz skoncentrowany na unikaniu ${ }^{18}$.

\section{Cel pracy}

Celem badań była próba odpowiedzi na następujące pytania badawcze:

- Jakie są różnice w stylu radzenia sobie ze stresem w grupie matek i ojców?

- Jakie są różnice w stylu radzenia sobie ze stresem w grupach rodziców dzieci z autyzmem i zespołem Aspergera?

- Jakie są różnice w stylu radzenia sobie ze stresem w grupach wyróżnionych z uwagi na miejsce zamieszkania rodziców?

- Jakie style radzenia sobie ze stresem preferują rodzice dzieci $\mathrm{z}$ autyzmem?

\section{Metoda}

Badania zrealizowano $\mathrm{w}$ oparciu o metodę sondażu diagnostycznego przy zastosowaniu następujących technik:

I. Heszen-Niejodek, Z. Ratajczak, Wydawnictwo Uniwersytetu Śląskiego, Katowice 1996, s. 95.

17 A.M. Colman, Stownik psychologii, PWN, Warszawa 2009, s. 710.

18 N.S. Endler, J.D.A. Parker, Coping Inventary for Stressful Situations (CISS): Manual, Multi-Health Systems, Toronto 1990. 
1. Kwestionariusz CISS ${ }^{19}$ służący do pomiaru stylów radzenia sobie ze stresem. Kwestionariusz CISS składa się z 48 stwierdzeń dotyczących różnych ludzkich zachowań, podejmowanych w sytuacjach stresowych. Badany ma za zadanie określić na pięciostopniowej skali częstotliwość, z jaką podejmuje dane działanie w sytuacjach trudnych, stresowych. Wyniki ujmowane są na trzech podskalach: SSZ - styl skoncentrowany na zadaniu; SSE - styl skoncentrowany na emocjach; SSU - styl skoncentrowany na unikaniu. Ten ostatni styl może przyjmować dwie formy: ACZ - angażowanie się w czynności zastępcze i PKT - poszukiwanie kontaktów towarzyskich. Wyniki surowe zostały przeliczone na jednostki normalizacyjne zwane stenami z uwzględnieniem kryterium wieku.

Kwestionariusz CISS cechuje się wysoką zgodnością wewnętrzną poszczególnych skal (współczynniki w granicach 0,78-0,90) oraz zadowalająca stabilnością (współczynniki korelacji między dwukrotnym badaniem w odstępie 2-3 tygodni w granicach 0,73-0,80) ${ }^{20}$.

2. Wywiad (ankieta własnego autorstwa) dotyczący sytuacji socjoekonomicznej osób badanych.

\section{Wyniki badań}

Przedstawione wyniki badań stanowią część szerszego projektu badań realizowanego w okresie od stycznia 2016 do kwietnia 2017 r. na terenie trzech województw: mazowieckiego, lubelskiego i podkarpackiego. Spośród ogółu badanych wyłoniono 132 rodziców dzieci z autyzmem, w tym 105 matek i 27 ojców. Średni wiek badanych to 40,3 lat, w tym ojcowie 41,9 lat i matki 38,7 lat.

W tabeli 1. przedstawiono dane dotyczące różnic w zakresie wyników uzyskanych w skali CISS przez matki i ojców. Analiza

${ }^{19}$ N.S. Endler, J.D.A. Parker, op. cit.

20 J. Strelau, A. Jaworowska, K. Wrześniewski, P. Szczepaniak, Kwestionariusz Radzenia Sobie w Sytuacjach Stresowych. Podręcznik do polskiej normalizacji, Pracownia Testów Psychologicznych PTP, Warszawa 2009. 
wyników wskazuje na istnienie różnic między badanymi rodzicami co do stylu skoncentrowanego na unikaniu - SSU $(p<0,05)$ i angażowaniu się w czynności zastępcze - ACZ $(p<0,05)$. W obydwu przypadkach matki wykazują większą tendencję do wykorzystywania tych stylów aniżeli ojcowie.

Tabela 1. Różnice w zakresie średnich arytmetycznych i odchylenia standardowego uzyskanych w skali CISS przez kobiety i mężczyzn (1 - matki; 2 - ojcowie)

\begin{tabular}{|c|c|c|c|c|c|}
\hline $\begin{array}{c}\text { Style radzenia sobie } \\
\text { ze stresem }\end{array}$ & Płeć & $\mathrm{N}$ & $x \square$ & $\mathrm{S}$ & $\begin{array}{c}p \\
\text { Testu U } \\
\text { Manna Whitneya }\end{array}$ \\
\hline $\begin{array}{l}\text { SSZ - styl skoncentrowa- } \\
\text { ny na zadaniu }\end{array}$ & $\begin{array}{l}1 \\
2\end{array}$ & $\begin{array}{r}105 \\
27\end{array}$ & $\begin{array}{l}57,14 \\
57,96\end{array}$ & $\begin{array}{l}8,42 \\
6,58 \\
\end{array}$ & 0,633 \\
\hline $\begin{array}{l}\text { SSE - styl skoncentrowa- } \\
\text { ny na emocjach }\end{array}$ & $\begin{array}{l}1 \\
2\end{array}$ & $\begin{array}{r}105 \\
27\end{array}$ & $\begin{array}{l}42,28 \\
38,25\end{array}$ & $\begin{array}{r}11,81 \\
9,46\end{array}$ & 0,131 \\
\hline $\begin{array}{l}\text { SSU - styl skoncentrowa- } \\
\text { ny na unikaniu }\end{array}$ & $\begin{array}{l}1 \\
2\end{array}$ & $\begin{array}{r}105 \\
27\end{array}$ & $\begin{array}{l}44,70 \\
40,22\end{array}$ & $\begin{array}{l}8,52 \\
9,54\end{array}$ & $0,020^{*}$ \\
\hline $\begin{array}{l}\text { ACZ - angażowanie się } \\
\text { w czynności zastępcze }\end{array}$ & $\begin{array}{l}1 \\
2\end{array}$ & $\begin{array}{r}105 \\
27\end{array}$ & $\begin{array}{l}19,94 \\
17,37\end{array}$ & $\begin{array}{l}5,06 \\
4,93\end{array}$ & $0,028^{*}$ \\
\hline $\begin{array}{l}\text { PKT - poszukiwanie kon- } \\
\text { taktów towarzyskich }\end{array}$ & $\begin{array}{l}1 \\
2\end{array}$ & $\begin{array}{r}105 \\
27\end{array}$ & $\begin{array}{l}16,60 \\
15,55\end{array}$ & $\begin{array}{l}3,8 \\
3,895\end{array}$ & 0,178 \\
\hline
\end{tabular}

* $P<0,05$

W dalszej kolejności porównano średnie arytmetyczne i odchylenia standardowe uzyskane w skali CISS przez rodziców dzieci z autyzmem i rodziców dzieci z zespołem Aspergera (tabela 2). Różnice okazały się nieistotne we wszystkich podskalach mierzących poszczególne rodzaje stylów radzenia sobie ze stresem.

W literaturze przedmiotu często podnosi się, że miejsce zamieszkania ma ogromny wpływ na sytuację rodziny $\mathrm{z}$ dzieckiem niepełnosprawnym lub zaburzonym $\mathrm{w}$ rozwoju ${ }^{21}$. $\mathrm{Z}$ tego powodu

${ }^{21}$ Np.: W. Otrębski, K. Konefał, K. Mariańczyk, M.M. Kulikn, Wspieranie rodziny $z$ niepetnosprawnym dzieckiem wyzwaniem dla pracy socjalnej, Europerspektywa Beata Romejko, Lublin 2011; A. Twardowski, op. cit. 
Tabela 2. Różnice $w$ zakresie średnich arytmetycznych i odchylenia standardowego uzyskanych w skali CISS przez rodziców dzieci z autyzmem i zespołem Aspergera (1 - rodzice dzieci z Autyzmem; 2 - rodzice dzieci z zespołem Aspergera)

\begin{tabular}{|c|c|c|c|c|c|}
\hline $\begin{array}{l}\text { Style radzenia sobie } \\
\text { ze stresem }\end{array}$ & Grupy & $\mathrm{N}$ & $\mathrm{x} \square$ & $\mathrm{s}$ & $\begin{array}{c}P \\
\text { Testu U } \\
\text { Mnna Whitneya }\end{array}$ \\
\hline $\begin{array}{l}\text { SSZ - styl skoncentrowa- } \\
\text { ny na zadaniu }\end{array}$ & $\begin{array}{l}1 \\
2\end{array}$ & $\begin{array}{r}100 \\
32\end{array}$ & $\begin{array}{l}58,03 \\
55,06\end{array}$ & $\begin{array}{l}8,34 \\
6,77\end{array}$ & 0,066 \\
\hline $\begin{array}{l}\text { SSE - styl skoncentrowa- } \\
\text { ny na emocjach }\end{array}$ & $\begin{array}{l}1 \\
2\end{array}$ & $\begin{array}{r}100 \\
32\end{array}$ & $\begin{array}{l}41,90 \\
40,09\end{array}$ & $\begin{array}{l}11,54 \\
11,24\end{array}$ & 0,592 \\
\hline $\begin{array}{l}\text { SSU - styl skoncentrowa- } \\
\text { ny na unikaniu }\end{array}$ & $\begin{array}{l}1 \\
2\end{array}$ & $\begin{array}{r}100 \\
32 \\
\end{array}$ & $\begin{array}{l}44,59 \\
41,28 \\
\end{array}$ & $\begin{array}{l}9,11 \\
7,78 \\
\end{array}$ & 0,096 \\
\hline $\begin{array}{l}\text { ACZ - angażowanie się } \\
\text { w czynności zastępcze } \\
\end{array}$ & $\begin{array}{l}1 \\
2 \\
\end{array}$ & $\begin{array}{r}100 \\
32 \\
\end{array}$ & $\begin{array}{l}19,81 \\
18,18 \\
\end{array}$ & $\begin{array}{l}5,25 \\
4,58 \\
\end{array}$ & 0,098 \\
\hline $\begin{array}{l}\text { PKT - poszukiwanie kon- } \\
\text { taktów towarzyskich }\end{array}$ & $\begin{array}{l}1 \\
2\end{array}$ & $\begin{array}{r}100 \\
32 \\
\end{array}$ & $\begin{array}{l}16,65 \\
15,56 \\
\end{array}$ & $\begin{array}{l}3,88 \\
3,78\end{array}$ & 0,222 \\
\hline
\end{tabular}

Tabela 3. Różnice $\mathrm{w}$ zakresie średnich arytmetycznych i odchylenia standardowego uzyskanych w skali CISS przez rodziców w związku z miejscem zamieszkania (A - duże miasto; B - małe miasto; C - wieś )

\begin{tabular}{|c|c|c|c|c|c|c|c|c|c|}
\hline $\begin{array}{l}\text { Style radzenia } \\
\text { sobie ze stresem }\end{array}$ & F & $d f$ & $p$ & Gr & $\mathrm{N}$ & $\mathrm{X} \square$ & S & $\begin{array}{l}\text { Porówna- } \\
\text { nie grup }\end{array}$ & $\begin{array}{c}p \\
\text { post testu NIR }\end{array}$ \\
\hline \multirow{3}{*}{$\begin{array}{l}\text { SSZ - styl skon- } \\
\text { centrowany na za- } \\
\text { daniu }\end{array}$} & 4,026 & 2 & $0,020^{*}$ & A & 52 & 57,25 & 8,04 & \multirow{3}{*}{ B-C } & \multirow{3}{*}{$0,005^{* *}$} \\
\hline & & & & B & 36 & 54,58 & 7,72 & & \\
\hline & & & & C & 44 & 59,61 & 7,84 & & \\
\hline \multirow{3}{*}{$\begin{array}{l}\text { SSE - styl skon- } \\
\text { centrowany na } \\
\text { emocjach }\end{array}$} & 0,122 & 2 & 0,885 & A & 52 & 41,53 & 11,58 & & \\
\hline & & & & B & 36 & 42,11 & 10,81 & & \\
\hline & & & & C & 44 & 40,84 & 12,03 & & \\
\hline \multirow{3}{*}{$\begin{array}{l}\text { SSU - styl skon- } \\
\text { centrowany na uni- } \\
\text { kaniu }\end{array}$} & 1,415 & 2 & 0,247 & A & 52 & 43,46 & 9,45 & & \\
\hline & & & & B & 36 & 42,19 & 7,90 & & \\
\hline & & & & C & 44 & 45,47 & 8,88 & & \\
\hline \multirow{3}{*}{$\begin{array}{l}\text { ACZ - angażowa- } \\
\text { nie się w czynno- } \\
\text { ści zastępcze }\end{array}$} & 0,096 & 2 & 0,908 & A & 52 & 19,34 & 5,15 & & \\
\hline & & & & B & 36 & 19,19 & 4,94 & & \\
\hline & & & & C & 44 & 19,68 & 5,35 & & \\
\hline \multirow{3}{*}{$\begin{array}{l}\text { PKT - poszukiwa- } \\
\text { nie kontaktów to- } \\
\text { warzyskich }\end{array}$} & 2,841 & 2 & $0,052^{*}$ & A & 52 & 16,15 & 3,89 & \multirow{3}{*}{ B-C } & \multirow{3}{*}{$0,022^{*}$} \\
\hline & & & & B & 36 & 15,44 & 3,62 & & \\
\hline & & & & C & 44 & 17,43 & 3,87 & & \\
\hline
\end{tabular}

${ }^{*} \mathrm{p}<0,05 ;{ }^{* *} \mathrm{p}<0,01$ 
uznano za konieczne porównanie wyników uzyskanych przez rodziców zamieszkujących różne środowiska (tabela 3). Porównanie średnich arytmetycznych oraz odchylenia standardowego (ANOVA) w skali CISS uzyskanych przez osoby zamieszkujące duże miasta, małe miasta i wieś wskazuje na istotne różnice w skali SSZ - mierzącej styl skoncentrowany na rozwiązaniach $F(2)=4,026 ; p<0,020$ i PKT - mierzącej styl nastawiony na poszukiwanie kontaktów towarzyskich $F(2)=2,841 ; p<0,052$. Analiza porównań $\mathrm{w}$ diadach dokonana przy pomocy post testu NIR wskazuje, że w obydwu przypadkach rodzice dzieci z autyzmem zamieszkujący wieś zdecydowanie częściej aniżeli rodzice zamieszkujący małe miasta stosują styl skoncentrowany na zadaniu $(p<0,005)$ i poszukiwaniu kontaktów towarzyskich $(p<0,022)$.

Wykresy 1-5 przedstawiają profil wyników uzyskanych w skali CISS przez rodziców dzieci $z$ autyzmem $w$ poszczególnych podskalach.

Wykres 1. Profil wyników przeliczonych (w stenach) uzyskanych w podskali mierzącej styl skoncentrowany na zadaniu (SSZ)

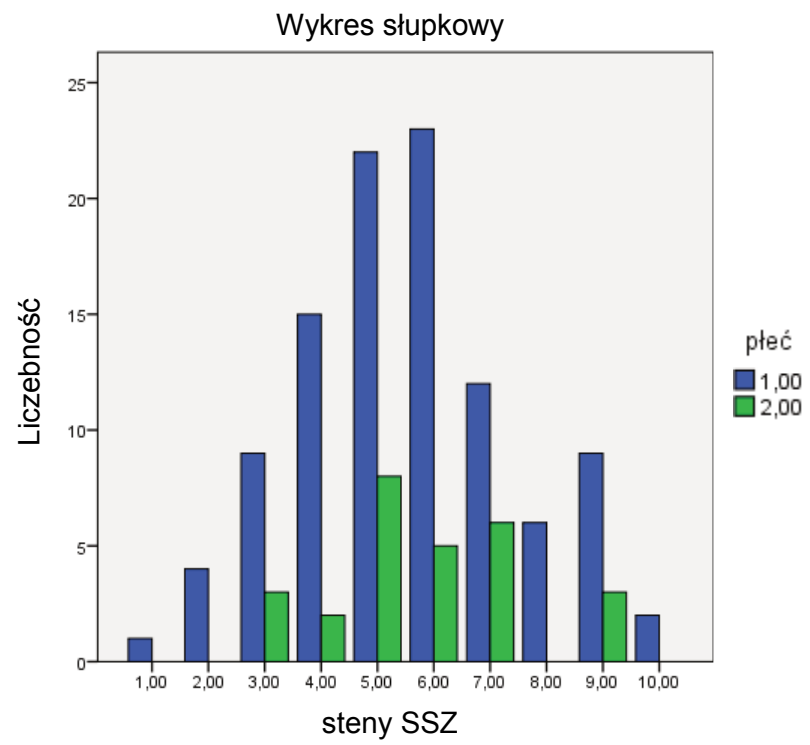


Profil wyników uzyskanych w skali CISS przedstawiony na wykresie 1. wskazuje na dominację wśród badanych rodziców dzieci z autyzmem stenów średnich. Oznacza to, że styl skoncentrowany na zadaniu występuje $\mathrm{w}$ stopniu przeciętnym $\mathrm{w}$ badanej populacji. Styl skoncentrowany na zadaniu charakteryzuje ludzi, którzy doświadczając stresu, starają się przede wszystkim zidentyfikować problem stanowiący jego źródło, by następnie zabrać się do rozwiązanie tego problemu. W sytuacji, gdy rozwiązanie nie jest możliwe, starają się dostosować do życia w nowej, zmienionej sytuacji. Przyjmuje się, że dla osoby posiadającej styl skoncentrowany na zadaniu zwykle jest to bardzo korzystne. Pozwala bowiem osobie przeżywającej stres w sposób szybki i skuteczny zabrać się za działanie i poradzić sobie z przyczynami stresu.

Wykres 2. Profil wyników przeliczonych (w stenach) uzyskanych w podskali mierzącej styl skoncentrowany na emocjach (SSE)

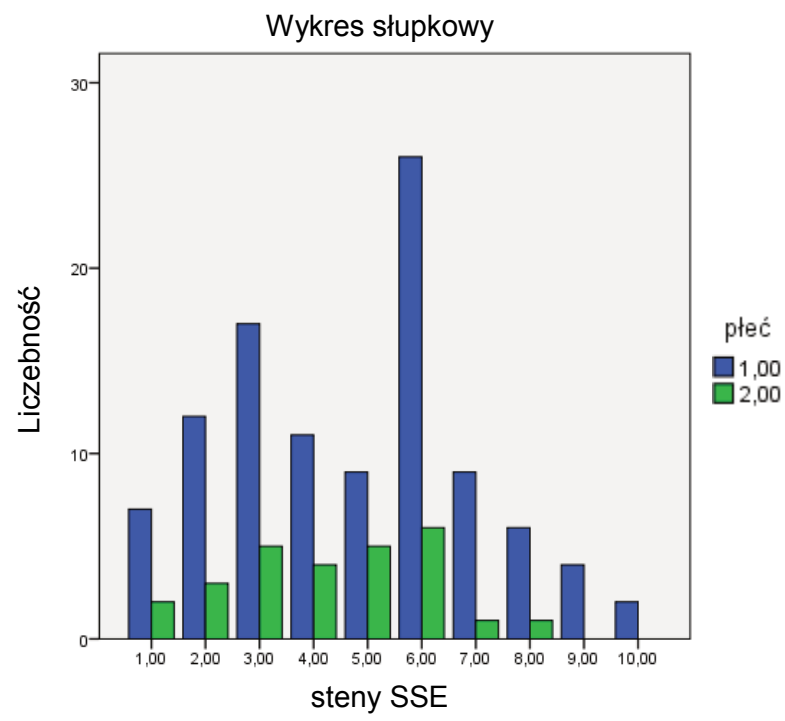

Wykres 2. zawiera profil wyników uzyskanych w skali CISS określanych jako styl skoncentrowany na emocjach. Dominacja 
stenów średnich i niskich wskazuje, że badani rodzice dzieci $\mathbf{z}$ autyzmem $\mathrm{w}$ sytuacji stresowej $\mathbf{w}$ stopniu średnim lub niskim stosują styl skupiający się głównie na emocjach. W zależności od tego, co spowodowało stres, emocje mogą być różne, ale raczej nie należą do przyjemnych. Strategie związane z tym stylem polegają głównie na przeżywaniu i próbach rozładowania emocji. Wyrazem tego może być zamartwienie się różnymi sprawami, próby wyżalania się do innej osoby, jak również fantazjowanie czy też myślenie życzeniowe w rodzaju „następnym razem mi się uda” bez podejmowania jakichkolwiek starań, żeby się udało.

Wykres 3. Profil wyników przeliczonych (w stenach) uzyskanych w podskali mierzącej styl skoncentrowany na unikaniu (SSU)

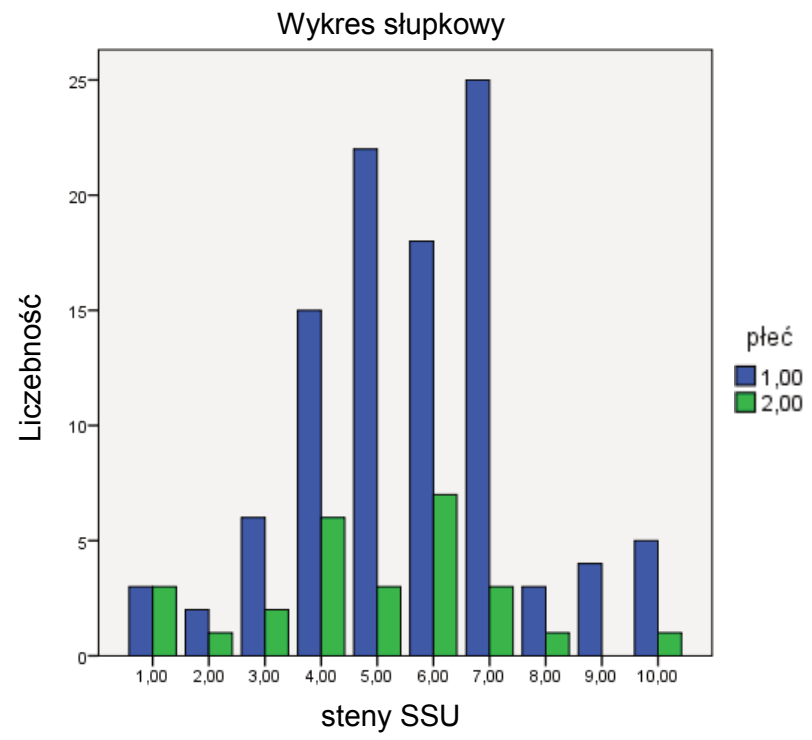

Wyniki w podskali mierzącej styl skoncentrowany na unikaniu - SSU (wykres 3.), wyraźnie wskazuje na dominacje stenów średnich. Oznacza to, że w badanej grupie osób w stopniu średnim rodzice stosują styl zorientowany na unikanie, starając się unikać 
myślenia o problemie będącym źródłem stresu. Zgodnie z teoretycznymi założeniami autorów skali strategie, które wiążą się z tym stylem, polegają głownie na zajmowaniu czymś swojej uwagi i odwracaniu jej od myślenia o problemie i jego konsekwencjach.

Wykres 4. zawiera profil wyników uzyskanych przez badanych rodziców w podskali mierzącej styl skoncentrowany na angażowaniu się w czynności zastępcze (ACZ). Dominacja wyników średnich wskazuje na angażowanie się $\mathrm{W}$ stopniu przeciętnym w czynności zastępcze w postaci unikania sytuacji stresowej poprzez oglądanie telewizji, objadanie się, myślenie o sprawach przyjemnych, sen.

Wykres 4. Profil wyników przeliczonych (w stenach) uzyskanych w podskali mierzącej styl skoncentrowany na angażowaniu się w czynności zastępcze (ACZ)

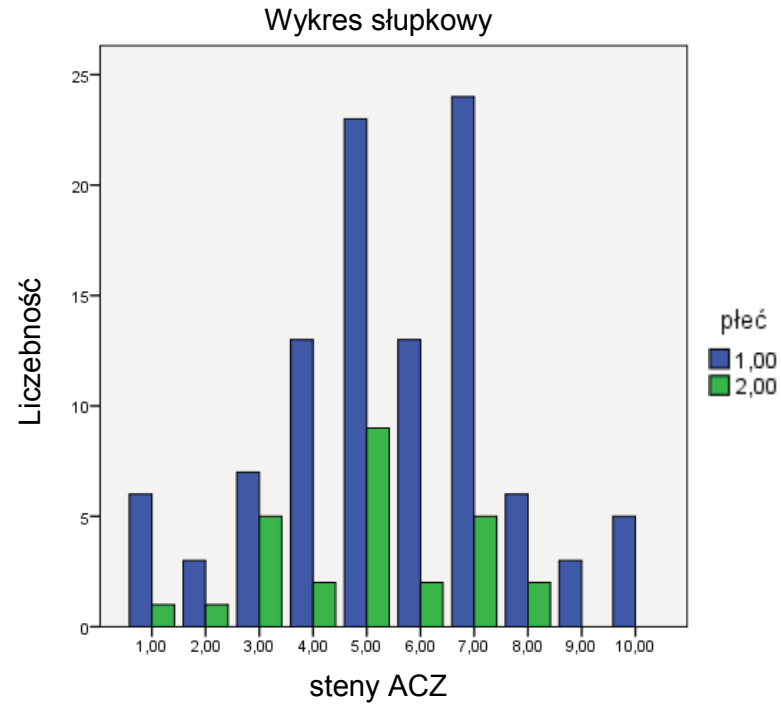

Wykres 5. zawiera profil wyników w skali poszukiwanie kontaktów towarzyskich (PKT). Dominacja wyników średnich wskazuje na unikanie sytuacji stresowej w stopniu przeciętnym poprzez wchodzenie w interakcje społeczne. 
Wykres 5. Profil wyników przeliczonych (w stenach) uzyskanych w podskali mierzącej styl skoncentrowany na poszukiwaniu kontaktów towarzyskich (PKT)

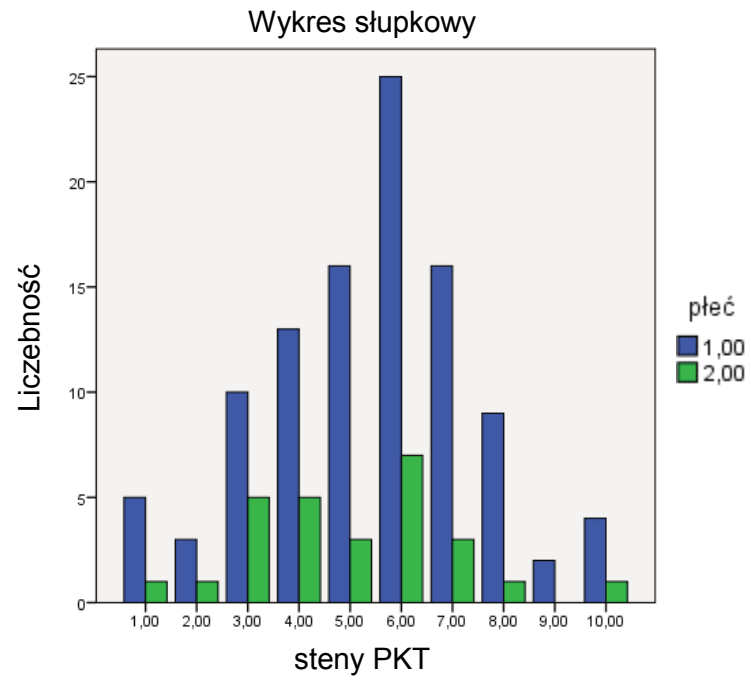

Ogólnie rzecz ujmując, analiza profilów wyników uzyskanych w poszczególnych podskalach CISS pozwala stwierdzić, że w przypadku badanych rodziców dzieci $\mathrm{z}$ autyzmem $\mathrm{w}$ najmniejszym stopniu występuje styl skierowany na emocje. Pozostałe style były $\mathrm{w}$ podobnym stopniu wybierane przez badanych (steny średnie).

\section{Dyskusja}

Celem przeprowadzonych badań było porównanie stylów radzenia sobie ze stresem matek i ojców, następnie rodziców dzieci z autyzmem i rodziców dzieci z zespołem Aspergera, wyodrębnionych grup rodziców z uwagi na miejsce zamieszkania, oraz analiza dominujących stylów radzenia sobie ze stresem wśród ogółu badanych.

Porównanie wyników uzyskanych w skali CISS w grupach matek i ojców wskazuje, że matki stosunkowo częściej niż ojcowie wykazują skoncentrowany na unikaniu (SSU) oraz styl angażowaniu 
się w czynności zastępcze (ACZ). Brak jest różnic w zakresie stosowanego stylu radzenia sobie ze stresem rodziców dzieci $\mathrm{z}$ autyzmem i rodziców dzieci z zespołem Aspergera. Ponadto rodzice dzieci z autyzmem zamieszkujący wieś zdecydowanie częściej aniżeli rodzice zamieszkujący małe miasta stosują styl skoncentrowany na zadaniu i poszukiwaniu kontaktów towarzyskich. Analiza profilu wyników uzyskanych w skali CISS pozwala stwierdzić, że rodzice dzieci $\mathrm{z}$ autyzmem w najmniejszym stopniu stosują styl skierowany na emocje. Pozostałe style były w podobnym stopniu (steny średnie) stosowane przez badanych.

Uzyskane wyniki badań nie pokrywają się z poglądami niektórych autorów polskich i zagranicznych. Ewa Pisula, powołując się na różne wyniki badań, dochodzi do wniosku, że rodzice dzieci ze spektrum autyzmu w większym stopniu stosują strategie radzenia sobie polegające na ucieczce od stresora, rzadziej poszukują wsparcia społecznego i rozwiązania problemów niż rodzice dzieci z innymi zaburzeniami w rozwoju ${ }^{22}$. Jednocześnie autorka podkreśla, że rodzice radzą sobie poprzez akceptowanie nieprzewidywalności i losowości zdarzeń oraz koncentrację na teraźniejszości, na bieżących problemach.

Liza Little podaje, że autyzm rozpoznany u dziecka w różnym stopniu obciąża matkę i ojca. Matki bardziej odczuwają stres związany z wychowywaniem niepełnosprawnego dziecka, częściej także korzystają z pomocy profesjonalistów oraz bardziej pesymistycznie myślą o przyszłości dziecka23. Wyniki badań zespołu badaczy Kennetha I. Pakenhama, Christiny Samios i Kate Sofronoff zdają się wskazywać, że najbardziej adaptacyjnym stylem radzenia sobie ze stresem w sytuacji rodzin dzieci z zespołem Aspergera okazał się styl skoncentrowany na emocjach ${ }^{24}$. Zdaniem autorów fakt posia-

22 E. Pisula, Rodzice dzieci z autyzmem, PWN, Warszawa 2012.

${ }^{23}$ L. Little, Differences in stress and coping for mothers and fathers of children with Asperger's syndrome and nonverbal learning disorder "Pediatric Nursing" 2002, 28, 6, s. 565-570.

${ }^{24}$ K.I. Pakenham, C. Samios, K. Sofronoff, Adjustment in mothers of children with Asperger syndrome: An application of the double ABCX model of family adjustment, "Autism" 2005, 9, 2, s. 191-212. 
dania dziecka z zespołem Aspergera jest dla tych rodziców chronicznym, niekontrolowalnym stresorem, przez co być może strategia zadaniowa nie jest dla nich możliwa. Według badaczy strategie zadaniowe mogą być $\mathrm{z}$ powodzeniem używane jedynie w tej sytuacji, gdy źródło stresu jest modyfikowalne, co ich zdaniem nie ma zastosowania w przypadku dziecka z zaburzeniami w rozwoju. Na podstawie kolejnych swoich badan K.I. Pakenham, C. Samios, K. Sofronoff dochodzą do wniosku, że oprócz stylu radzenia sobie ze stresem skoncentrowanym na emocjach, rodzice dzieci z zespołem Aspergera w ramach stylu adaptacyjnego wykazują również dwie inne strategie, tj: nadawania znaczenia niepełnosprawności dziecka oraz pozytywnej percepcji jego zaburzenia. Wyniki badań K.I. Pakenham, C. Samios, K. Sofronoff wskazują, że oba te czynniki w sposób pozytywny korelują ze społecznym wsparciem, poczuciem własnej skuteczności oraz adaptacyjnymi stylami radzenia sobie ze stresem ${ }^{25}$.

\section{Zakończenie}

Rozwój dziecka z autyzmem najczęściej jest nierównomierny, nieharmonijny, wręcz nieprzewidywalny i może wskazywać na postęp, jego brak, jak i regres rozwojowy. Powoduje to, że negatywne stany emocjonalne rodziców związane z opieką i wychowywaniem dziecka $z$ autyzmem są obecne na każdym etapie rozwoju dziecka, dotyczą każdego nowego wydarzenia w jego życiu²6. Dlatego rodzice potrzebują stałego wsparcia ze strony osób bliskich, znajomych oraz profesjonalistów ${ }^{27}$. Rozumienie sytuacji emocjonal-

${ }^{25}$ K.I. Pakenham, C. Samios, K. Sofronoff, Finding meaning in parenting a child with Asperger syndrome: correlates of sense making and benefit finding, "Research in Developmental Disabilities" 2004, 25, s. 245-264.

26 A. Banasiak, Psychospołeczny wymiar jakości życia rodzin dzieci z autyzmem, Prace Naukowe Akademii im. Jana Długosza w Częstochowie, "Seria Psychologia” 2008, z. XV.

27 Patrz: M. Pągowska Psychospoteczna sytuacja rodziny dziecka z autyzmem - etapy adaptacji do niepetnosprawności dziecka „Szkoła Specjalna” 2010, nr 4, s. 258-266. 
nej rodziców jest warunkiem wstępnym do planowania i realizacji wsparcia. Styl radzenia sobie ze stresem rodziców należy do podstawowych czynników branych pod uwagę w procesie terapii.

Przedstawione wyniki analiz dowodzą konieczności prowadzenia dalszych, szerszych oraz longitudinalnych badań dotyczących funkcjonowania emocjonalnego rodziców dzieci z autyzmem, jak również działań w zakresie wsparcia i terapii rodziców.

\section{Bibliografia}

Banasiak A., Psychospołeczny wymiar jakości życia rodzin dzieci z autyzmem, Prace Naukowe Akademii im. Jana Długosza w Częstochowie, „Seria Psychologia” 2008, z. XV.

Borowicz A., Stres rodziców wychowujących dzieci z niepetnosprawnościa stuchowa, „Niepełnosprawność - zagadnienia, problemy, rozwiązania” 2012, nr II.

Colman A.M., Stownik psychologii, PWN, Warszawa 2009.

Dudek M., Dzieci z zespołem ADHD w środowisku rodzinnym. Studium empiryczne, Wydawnictwo Adam Marszałek, Torun 2015.

Endler N.S., Parker J.D.A., Coping Inventary for Stressful Situations (CISS): Manual, Multi-Health Systems, Toronto 1990.

Gałkowski T., Dziecko autystyczne w środowisku rodzinnym, WSiP, Warszawa 1995.

Garncarz-Podlasko A., Sytuacja psychospołeczna rodziców dzieci autystycznych w kontekście zespołu wypalania sił, [w:] Autyzm wyzwaniem naszych czasów, red. T. Gałkowski, J. Kossewska, Wydawnictwo Naukowe Akademii Pedagogicznej, Kraków 2001.

Heszen-Niejodek I., Teoria stresu psychologicznego i radzenia sobie, [w:] Psychologia, t. 3, red. J. Strelau, GWP, Gdańsk 1999.

Huber L., Style adaptacyjne do sytuacji stresowych w różnych grupach wiekowych a choroby cywilizacyjne XXI wieku, „Problemy Higieny i Epidemiologii” 2010, 91(2).

Jaklewicz H., Autyzm wczesnodziecięcy. Diagnoza, przebieg, leczenie, GWP, Gdańsk 1993.

Janis I.L., Psychological stress: Psychoanalytic and behavioral studies of surgical patients, Wiley, New York 1958.

Johnson N., Frenn M., Feetham S., Simpson P., Autism spectrum disorder: parenting stress, family functioning and health- related quality of life, "Family, System \& Health" 2011, 29.

Lazarus R.S., Folkman S., Stress, appraisal, and coping, International Classification of Diseases 10th Revision,World Health Organization, Springer, New York 2010. Lazarus R.S., Paradygmat stresu i radzenia sobie, „Nowiny Psychologiczne” 1986, 3-4. 
Little L., Differences in stress and coping for mothers and fathers of children with Asperger's syndrome and nonverbal learning disorder, "Pediatric Nursing" 2002, 28, 6.

Ogińska-Bulik N., Juczyński Z., Osobowość, stres a zdrowie. Difin, Warszawa 2008.

Otrębski W., Konefał K., Mariańczyk K., Kulikn M.M., Wspieranie rodziny z niepetnosprawnym dzieckiem wyzwaniem dla pracy socjalnej, Europerspektywa Beata Romejko, Lublin 2011.

Pakenham K.I., Samios C., Sofronoff K., Finding meaning in parenting a child with Asperger syndrome: correlates of sense making and benefit finding, "Research in Developmental Disabilities" 2004, 25.

Pakenham K. I., Samios C., Sofronoff K., Adjustment in mothers of children with Asperger syndrome: An application of the double ABCX model of family adjustment, "Autism" 2005, 9, 2.

Patyk K., Rodzice dzieci autystycznych wobec sytuacji trudnych „Problemy OpiekuńczoWychowawcze" 2009.

Pągowska M., Psychospołeczna sytuacja rodziny dziecka z autyzmem - etapy adaptacji do niepetnosprawności dziecka, „Szkoła Specjalna” 2010, nr 4.

Pisula E, Małe dziecko z autyzmem, Gdańskie Wydawnictwo Psychologiczne, Gdańsk 2005.

Pisula E., Noińska D., Stres rodzicielski i percepcja doświadczeń związanych z opieka nad dzieckiem u rodziców dzieci z autyzmem uczestnicząych w różnych formach terapii, „Psychologia Rozwojowa” 2011, tom 16, nr 3.

Pisula E., Psychologiczne problemy rodziców dzieci z zaburzeniami rozwoju, Wydawnictwa UW, Warszawa 1998.

Pisula E., Rodzice dzieci z autyzmem, PWN, Warszawa 2012.

Pisula E., Zespót wypalania się sił u rodziców dzieci autystycznych, „Nowiny Pedagogiczne" 1994, 3.

Pyżalski J., Wypalenie zawodowe a zdrowie $i$ zachowania zdrowotne pedagogów placówek resocjalizacyjnych, „Medycyna Pracy” 2002, 6.

Rajner A., Wroniszewski M., Można im pomóc. Specjalistyczne ustugi opiekuńcze dla dzieci z autyzmem, SYNAPSIS, Warszawa 2002.

Randall P., Parker J., Autyzm. Jak pomóc rodzinie, GWP, Gdańsk 2016.

Sekułowicz M., Niektóre problemy funkcjonowania rodziny dziecka autystycznego, [w:] Autyzm kontrowersje i wyzwania, red. W. Dykcik, Wydawnictwo Eruditus, Poznań 1994.

Selye H., Stres okietznany, PIW, Warszawa 1979.

Strelau J., Jaworowska A., Wrześniewski K., i wsp., Kwestionariusz Radzenia Sobie w Sytuacjach Stresowych. Podręcznik do polskiej normalizacji, Pracownia Testów Psychologicznych Polskiego Towarzystwa Psychologicznego, Warszawa 2009.

Strelau J., Jaworowska A., Wrześniewski K., Szczepaniak P., Kwestionariusz Radzenia Sobie w Sytuacjach Stresowych. Podręcznik do polskiej normalizacji. Pracownia Testów Psychologicznych PTP, Warszawa 2009. 
Strelau J., Temperament a stres: Temperament jako czynnik moderujacy stresory, stan $i$ skutki stresu oraz radzenie sobie ze stresem, [w:] Człowiek w sytuacji stresu, red. I Heszen-Niejodek, Z. Ratajczak, Wydawnictwo Uniwersytetu Śląskiego, Katowice 1996.

Twardowski A., Sytuacja rodzin dzieci niepetnosprawnych, [w:] Dziecko niepetnosprawne w rodzinie, red. I. Obuchowska, WSiP, Warszawa 2008. 